\title{
Sanal Market Alışverişi Yapma Niyetinde Genişletilmiş Teknoloji Kabul Modeli Bileşenleri ile Risk Algılarının Etkisi
}

\author{
İrem Çakıra, b, İpek Kazançoğluc
}

\section{Özet}

İnternet ve mobil teknolojilerin kullanımının yaygınlaşması ile e-perakende uygulamaları hızla benimsenmiştir. Fakat hızlı tüketim ürünlerinin satışa sunulduğu sanal market alışverişlerinin benimsenme ve kullanım oranları çok daha yavaş artış göstermektedir. Sanal market alışverişinin kullanım oranlarının artırılması ve gelişmekte olan pazar yapısına veri sağlanabilmesi için, bu kanalların kabulünü etkileyen faktörler ile risk algılarının incelenmesi önemlidir. Bu amaç doğrultusunda gerçekleştirilen çalışmanın kavramsal çerçevesi Genişletilmiş Teknoloji Kabul Modeli 2 (UTAUT2) 'ye dayanmaktadır. 402 kişiye anket uygulanarak gerçekleştirilen araştırmada kolaylaştırıcı unsuların, alışkanlığın, performans beklentisinin ve zaman riskinin pozitif; psikolojik riskin ise negatif yönlü etkisinin olduğu tespit edilmiştir.

\section{Anahtar Kelimeler \\ Sanal Market Alışverişi \\ Çevrimiçi Alışveriş \\ Genişletilmiş Teknoloji Kabul \\ Modeli 2 (UTAUT2) \\ Risk Algiları \\ Makale Hakkında \\ Geliş Tarihi: 05.02.2020 \\ Kabul Tarihi: 10.06.2020 \\ Doi: 10.18026/cbayarsos.685067}

\section{The Effect of Risk Perceptions on the Intention to Online Grocery Shopping with Extended Technology Acceptance Model Components}

\section{Abstract}

E-retail applications have been rapidly adopted with the widespread use of internet and mobile technologies. However, the rates for the adoption and the use of shopping from online grocery markets, where fast-moving consumer goods are increasing much more slowly. It is important to examine the factors affecting the acceptance of these channels and risk perceptions in order to increase the rates of shopping from online grocery markets and to provide data to the emerging market structure. The conceptual framework of the study carried out for this purpose is based on the Unified Theory of Acceptance and Use of Technology 2 (UTAUT2). In the study conducted by applying a survey to 402 individuals, it was found that facilitating conditions, habits, performance expectancy and time risk had a positive whereas psychological risk negative impact on the intention of shopping from online grocery markets.
Keywords

Online grocery shopping

Online shopping

Unified Theory of Acceptance and Use of Technology 2

(UTAUT2)

Perceived Risk

About Article

Received: 05.02.2020

Accepted: 10.06 .2020

Doi: 10.18026/cbayarsos.685067

a İletissim Yazarı: irem-cakir@outlook.com.tr

b Doktora Öğrencisi, Ege Üniversitesi, Sosyal Bilimler Enstitüsü, irem-cakir@ outlook.com.tr, ORCIDD: 0000-0001-6572-7348

c Doç. Dr., Ege Üniversitesi, İktisadi ve İdari Bilimler Fakültesi, ipek.savasci@ege.edu.tr, ORCID: 000-0001-8251-5451 


\section{Giriş}

Akıllı telefon penetrasyonundaki artış ve gelişen internet bağlantısı, tüketicinin gündelik yaşam pratiklerinin pek çok alanında olduğu gibi, alışveriş deneyiminde de değişim sürecini başlatmıştır. Bu kapsamda kullanımı yaygınlaşan e-perakendecilik, yer ve zaman kısıtlarını ortadan kaldıran yapısı sayesinde tüketicilere ulaşılmasını kolaylaştırmaktadır (Chu, ArcaUrze ve Cebollada-Calvo, 2010; Gupta ve Kim, 2010). Ayrıca tüketici davranışlarının daha kolay gözlemlenebilmesi sayesinde (Ferreira, 2009), kişiselleştirilmiş ürün ve hizmetlerin sunulması gibi firmalar için birçok avantajı da beraberinde getirmektedir (Chu ve diğerleri, 2010; Doherty ve Ellis-Chadwick, 2009; Lim, Widdows ve Hooker 2009). Tüketiciler ise, daha kolay fiyat karşılaştırması yapma, zaman ve enerjiden tasarruf etme (Chu ve diğerleri, 2010) gibi nedenlerle e-perakendecilik uygulamalarını hızla benimsemişlerdir.

E-perakendecilik uygulamaları tüketicilere ve firmalara pek çok avantaj sağlamaktadır. Ancak hızlı tüketim mallarının satışa sunulduğu sanal market alışverişinin perakendeciler ve tüketiciler tarafından benimsenme ve uygulanma oranları çok daha yavaş artış göstermektedir (Gore, 2017; Kureshi ve Thomas, 2019; Weber ve Badenhorst-Weiss, 2018). Nitekim, dünya genelinde \%70'lik oranla fiziksel kanallardan en fazla satın alınan kategori olan market ürünleri, çevrimiçi alışverişte \%23'lük oran ile en düşük satın alma oranına sahiptir (Statista, 2017). Sanal market alışverişinin, perakendeciler ve tüketiciler tarafından benimsenme ve uygulanma oranları ülkemizin de içerisinde yer aldığı gelişmekte olan ülkelerde çok daha yavaş artış göstermektedir (Gore, 2017; Kureshi ve Thomas, 2019; Weber ve Badenhorst-Weiss, 2018). Ülkeler bazında hızlı tüketim ürünlerinin çevrimiçi alışveriş payları incelendiğinde Güney Kore \%18, Çin \%16, İngiltere \%6,3, Fransa 6,1, Tayvan \%5,6, ABD \%5,4, Avustralya \%3 iken; Türkiye'nin \%2 ile sınırlı kaldığı görülmektedir (Nielsen, 2018). Twentify'in (2018) 2085 tüketicinin katılımıyla gerçekleştirdiği “Türkiye'de E-ticaret: Çevrimiçi Alışverişte Tüketici Davranışları Araştırması ve Marka Karşılaştırması" raporuna göre ülkemizdeki tüketicilerin çevrimiçi alışverişlerde en fazla satın aldıkları ürün grubu giyim olmakla birlikte; bunu elektronik, yemek siparişi, seyahat/konaklama ve kitap takip etmektedir (Twentify, 2018). Benzer şekilde 2011-2019 yılları arasında TÜİK tarafından gerçekleştirilen Hanehalkı Bilişim Teknolojileri Kullanım Araştırması sonuçları da, çevrimiçi alışveriş yapan tüketicilerin en çok satın aldıkları ürün kategorisinin giyim olduğunu göstermekte ve gida alışverişinin 2018 yılında çevrimiçi alışverişte \%22,1 olan oranının, 2019 yılında \%27,4'e çıktığını ortaya koymaktadır.

Sanal market alışverişinin düşük olan kullanım oranlarının arttırılması ve gelişmekte olan pazar yapısının güçlendirilmesi için, bu kanalların kabulünü etkileyen faktörler ile risk algılarının incelenmesi önemlidir. Literatür incelendiğinde sanal market alışverişinin kabulüne ve risk algılarına ilişkin ABD ve Avrupa'da birçok çalışma (Bauerova ve Klepek, 2018; Droogenbroeck ve Hove 2017; Güsken, Janssen ve Hees, 2019; Kian, Loong ve Fong, 2019; Mortimer, Hasan, Andrews ve Matin, 2016; Sreeram, Kesharwani, ve Desai, 2017) yapılmış olmasına karşın, bu sonuçların Türkiye gibi gelişmekte olan ülkelerde geçerliliğine ilişkin yeterli sayıda araştırma bulunmamaktadır (Driediger ve Bhatiasevi, 2019; Weber ve Badenhorst-Weiss, 2018). Sanal market alışverişi ile ilgili Türkçe literatürde ise, alışveriş motivasyonları (Candan ve Kurtuluş, 2003) ve alışveriş niyetinin sürekliliğini inceleyen nitel bir araştırma (İşçioğlu, 2017) ile sınırlı kaldığı görülmüştür.

$\mathrm{Bu}$ çalışmada sanal market alışverişinin benimsenmesinde etkili olan faktörler ile risk algılarının, alışveriş yapma niyeti üzerindeki etkisinin belirlenmesi amaçlanmıştır. Araştırma 
mevcut yazındaki boşluğun doldurulması ve henüz gelişmemiş olan sanal market pazarına yönelik veri sağlanması açısından önemlidir. Bu amaçlar doğrultusunda gerçekleştirilen çalışmanın kavramsal çerçevesi Genişletilmiş Teknoloji Kabul Modeli2 (UTAUT2)'ye dayanmaktadir.

\section{Sanal Market Alışverişinin Benimsenmesinde Etkili Olan Faktörler}

Sanal market alışverişi gıda, kişisel bakım, temizlik malzemeleri gibi hızlı tüketim ürünlerinin internet üzerinden satın alınmasına olanak sağlayan bir e-perakendecilik türüdür (European Commission, 2015).

Kullanıcıların sanal market alışverişini benimsemelerinde etkili olan faktörlerin anlaşılmasına yönelik gerçekleştirilen çalışmaların birçoğunun teorik çerçevesini Teknoloji Kabul Modeli (TAM) oluşturmaktadır (Driediger ve Bhatiasevi, 2019; Espegren, Carling ve Olsmants, 2018; Sreeram ve diğerleri, 2017; Loketkrawee ve Bhatiasevi, 2018). Davis, Bagozzi ve Warshaw (1989) tarafından ortaya konulan TAM, önceleri kurum çalışanlarının bilgi teknolojilerini benimsemelerinde etkili olan faktörlerin ortaya konulması amacı ile geliştirilmiştir. Model, teknolojinin benimsenmesi sürecini algılanan fayda ve algılanan kullanım kolaylı̆̆ı değişkenleri çerçevesinde ele almaktadır. Algılanan fayda, kişinin teknoloji kullanımının iş performansını arttıracağı beklentisi olarak tanımlanırken, algılanan kullanım kolaylığı ise teknoloji kullanımına ilişkin düşük çaba beklentisi olarak tanımlanmaktadır (Davis ve diğerleri, 1989). Model farklı bilgi teknolojilerinin benimsenmesinde etkili olan faktörleri açıklamada faydalı bulunsa da, davranışsal ve tutumsal bağlantıları çok iyi yansıtmamasından dolayı eleştirilmiştir (Benbasat ve Barki, 2007).

TAM'a yönelik getirilen eleştiriler doğrultusunda Genişletilmiş Teknoloji Kabul Modeli (UTAUT) geliştirilmiş olup, model yedi farklı teorinin ampirik karşılaştırması sonucunda ortaya çıkmıştır: TAM, Gerekçeli Eylemin Teorisi, Motivasyon Modeli, Planlı Davranış Teorisi, Kişisel Bilgisayar (PC) Kullanım Modeli, Yayılma Teorisi ve Sosyal Bilişsel Teori (Venkatesh, Morris, Davis ve Davis, 2003). UTAUT modeli performans beklentisi, çaba beklentisi, sosyal etki ve kolaylaştırıcı koşullar olmak üzere dört faktörden oluşmaktadır (Venkatesh ve diğerleri, 2003).

Son yıllarda tüketicileri hedef alan teknolojik uygulamalar, cihazlar ve hizmetlerin sayısında artış yaşanması ile birlikte, tüketicileri yeni teknolojileri kabul etmeye ve kullanmaya motive eden değişkenlerin incelenmesi gerekliliği doğmuştur (Stofega ve Llamas, 2009). UTAUT modeli teknolojinin kabulü ve kullanımının açıklanmasına yönelik olarak birçok çalışmada doğrulanmış olsa da, tüketici bakış açısını daha iyi yansıtan kapsamlı bir teoriye ihtiyaç duyulmuştur (Gupta, Dogra ve George, 2018; Negahban ve Chung, 2014; Paulo, Paulo, Tiago ve Sérgio, 2018).

UTAUT modelinin kısıtları göz önünde bulundurularak tüketici bakış açısını daha iyi yansıtan hedonik motivasyonlar, alışkanlık ve fiyat- değer değişkenlerinin eklenmesi ile yedi faktörlü bir yapı haline getirilen model, Genişletilmiş Teknoloji Kabul Modeli2 (UTAUT2) adını almıştır (Venkatesh, Thong ve Xu, 2012). UTAUT2 modeli farklı disiplinler ve görev ortamlarına yönelik yapılan birçok ampirik çalışma ile doğrulanmıştır (Gupta ve diğerleri, 2018; Li, Sarathy ve Xu 2011; Venkatesh ve diğerleri, 2012). Dolayısıyla bu çalışmanın teorik çerçevesini, tüketici bakış açısını yansıtma yeteneği daha yüksek olan ve daha ayrıntılı bir çerçeve sunan UTAUT2 modeli oluşturmaktadır. UTAUT2 modelini oluşturan değişkenler aşağıda ayrıntılı olarak ele alınmıştır. 


\section{Performans Beklentisi}

Performans beklentisi, tüketicinin bir teknolojiyi kullanımı sonucunda elde edeceği faydaya ilişkin beklentileridir (Venkatesh ve diğerleri, 2012). Market alışverişlerinin internet üzerinden gerçekleştirilmesi yoluyla fiziksel mağazalardan alışveriş yapılması için katlanılan trafik, satın alınan ürünlerin taşınması, park yeri arayışı ve uzun kasa kuyrukları gibi sorunlar ortadan kalmakta (Kaur, 2018), böylece zaman ve emekten tasarruf edilebilmektedir (Verhoef ve Langerak, 2001). Bu açıdan performans beklentisinin sanal market alışverişi yapma niyeti üzerinde pozitif yönlü etkisinin olması beklenir. Buna yönelik belirlenen hipotez \% 95 güven düzeyinde test edilmiştir.

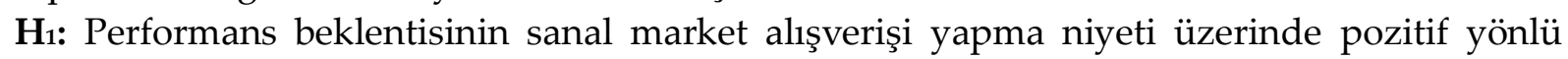
etkisi vardır.

\section{Çaba Beklentisi}

Çaba beklentisi, teknolojinin kullanımının kolay olarak algılanma derecesidir (Venkatesh ve diğerleri, 2012). Tüketici çok çaba harcamadan kullanıp, maksimum fayda sağlayacağ teknolojiyi benimsemeye daha eğilimlidir (Davis ve diğerleri, 1989). Bu sebeple sanal market kullanımına ilişkin çaba beklentisinin alışveriş yapma niyeti üzerinde pozitif yönlü etkisinin olması beklenir. Buna yönelik belirlenen hipotez \% 95 güven düzeyinde test edilmiştir.

$\mathbf{H}_{2}$ : Çaba beklentisinin sanal market alışverişi yapma niyeti üzerinde pozitif yönlü etkisi vardır.

\section{Sosyal Etki}

Sosyal etki, tüketicilerin önemli gördükleri kişilerin tavsiyeleri, düşünceleri ya da kullanımlarının teknoloji kullanımı kararındaki etkileri olarak tanımlanır (Venkatesh ve diğerleri, 2012). Çevresi tarafından sanal market alışverişi yapılan birey, market alışverişini internet üzerinden yapmaya eğilimli olacaktır. Ayrıca market alışverişinin internet üzerinden yapılması, toplum içerisinde imaj artırıcı bir araç olarak da kullanılabilir (Sreeram ve diğerleri, 2017). Bu sebepler doğrultusunda aşağıdaki hipotez geliştirilmiş olup, belirlenen hipotez \% 95 güven düzeyinde test edilmiştir.

$\mathbf{H}_{3}$ : Sosyal etkinin sanal market alışverişi yapma niyeti üzerinde pozitif yönlü etkisi vardır.

\section{Kolaylaştırıcı Koşullar}

Kolaylaştırıcı koşullar, yeni teknolojinin kullanımını destekleyen örgütsel ya da teknik altyapının olduğuna dair inançtır (Venkatesh ve diğerleri, 2012). Sanal market alışverişinin gerçekleştirilmesi yeterli düzeyde teknolojik bilgi ve donanıma sahip olunmasına bağlıdır (Sreeram ve diğerleri, 2017). Bu sebeple kolaylaştırıcı koşulların sanal market alışverişi yapma niyeti üzerinde pozitif yönlü etkisinin olması beklenir. Buna yönelik belirlenen hipotez \% 95 güven düzeyinde test edilmiştir.

$\mathbf{H}_{4}$ : Kolaylaştırıcı koşulların sanal market alışverişi yapma niyeti üzerinde pozitif yönlü etkisi vardır.

\section{Hedonik Motivasyon}

Hedonik motivasyon, teknolojilerin tüketiciler tarafından kullanılması sonucu elde ettikleri zevk veya mutluluktur (Venkatesh ve diğerleri, 2012). Hedonik motivasyon, yeni teknolojilerin tüketiciler tarafından benimsenmesi ve kullanılması üzerinde önemli bir etkiye 
sahiptir. Yapılan çalışmalar geleneksel perakendecilerden alışveriş yapılmasına kıyasla, çevrimiçi alışverişte hedonik motivasyonların daha belirleyici bir rol oynadığını ortaya koymaktadır (Escobar-Rodríguez ve Carvajal-Trujillo, 2014). Bu sebeple aşağıdaki hipotez geliştirilmiş olup, belirlenen hipotez \% 95 güven düzeyinde test edilmiştir.

Hs: Hedonik motivasyonun sanal market alışverişi yapma niyeti üzerinde pozitif yönlü etkisi vardır.

\section{Fiyat-Dĕger}

Fiyat-değer değişkeni, tüketicilerin yeni teknolojiyi kullanımı sonucunda elde ettikleri faydalar ile bu teknoloji için yaptıkları harcamalar arasındaki ilişkiye dayalı olarak oluşmaktadır (Venkatesh ve diğerleri, 2012). Market alışverişinin internet üzerinden gerçekleştirilmesinin katlanılan maliyete değeceğine ilişkin düşünceler, sanal market alışverişi yapma niyetini etkileyecektir. Bu bağlamda aşağıdaki hipotez geliştirilerek, \% 95 güven düzeyinde test edilmiştir.

H6: Fiyat- değer değişkeninin sanal market alışverişi yapma niyeti üzerinde pozitif yönlü etkisi vardır.

\section{Alışkanlık}

Alışkanlık, insanların öğrenme sonucunda bir davranışı otomatik olarak sergileme eğilimidir (Venkatesh ve diğerleri 2012). Bu kavram UTAUT2 modelinde yeni bir faktör olarak ele alınmaktadır. Alışkanlık, birçok çalışmada teknolojinin benimsenmesinin önemli bir öngörücüsü olarak kabul edilmekte (Kim ve Malhotra, 2005; Limayem, Hirt ve Cheung, 2007) ve satın alma niyetini doğrudan etkilemektedir. Sanal market alışveriş kanallarının daha önce kullanılmış olmasının, alışveriş yapma niyeti üzerinde pozitif yönlü etkisinin olması beklenir. $\mathrm{Bu}$ sebeple aşağıdaki hipotez geliştirilerek \%95 güven düzeyinde test edilmiştir.

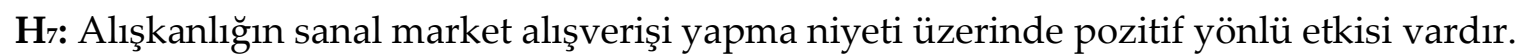

\section{Sanal Market Alışverişi Yapma Niyetini Etkileyen Risk Algıları}

Risk algısı, kişinin satın alma sürecinde olumsuz durumlarla karşılaşabileceğine yönelik endişeleridir (Dowling ve Staelin, 1994). Gıda ürünlerini de içerisinde barındıran hızlı tüketim ürünlerinin tazeliğine, kalitesine ve bozulmuş olabileceğine yönelik endişeler, tüketicilerin bu ürün gruplarına yönelik daha seçici, şüpheci ve temkinli davranmasına neden olmaktadır. Dolayısıyla risk algıları, sanal market alışverişinin benimsenmesinde önemli engeller olarak gösterilmektedir (Citrin, Stem, Spangenberg ve Clark, 2003; Huang ve Oppewal 2006; Mortimer ve diğerleri, 2016; Tsiros ve Heilman 2005). Benzer şekilde UTAUT2 modeline risk algılarının dahil edildiği çalışmalar mevcuttur (Alalwan, Dwivedi, Rana ve Algharabat, 2018; Dogra ve George, 2017; Shaw ve Sergueeva, 2019; Tandon, Kiran ve Sah, 2016). Risk algıları literatürde farklı boyutlar çerçevesinde ele alınsa da çalışma kapsaminda ele alınan boyutlar; performans riski, finansal risk, zaman riski, fiziksel risk, psikolojik risk ve sosyal risktir (Stone ve Gronhaug, 1993).

\section{Performans Riski}

Performans riski, ürünün vaat edilen faydaları yerine getiremeyeceğinden kaynaklı endişelerdir (Hassan, Kunz, Pearson ve Mohamed, 2006; Horton, 1976). İnternetin doğas1 gereği sanal market alışverişlerinde satın alınacak ürün dokunulup, hissedilememektedir. Bu 
durum sanal market alışverişine konu olan ürünler için başlı başına bir endişe kaynağıyken, özellikle gıda alışverişinde daha seçici, şüpheci ve temkinli olan tüketiciler ürünün kalitesi ile ilgili daha yoğun endişeler yaşayabilmektedirler (Hassan ve diğerleri, 2006; Huang ve Oppewal, 2006: 339; Kaur, 2018; Park, Kim, Funches ve Foxx, 2012; Picot-Coupey, Hure, Cliquet ve Petr, 2009). Bu sebeple aşağıdaki hipotez geliştirilerek, \%95 güven düzeyinde test edilmiştir

Hs: Performans riskinin sanal market alışverişi yapma niyeti üzerinde negatif yönlü etkisi vardır.

\section{Finansal Risk}

Finansal risk, bir ürünün satın alımı sonucunda parasal kayıp yaşanabileceğine ilişkin endişelerdir (Hassan ve diğerleri, 2006; Jacoby ve Kaplan, 1972; Roselius,1971). Sanal market alışverişleri lojistik ile ilgili maliyetlerden etkilenir. Gündelik hayatın bir parçası olan market alışverişlerinde fiyat duyarlılı̆̆ı daha yüksek olan tüketicilerin (Seitz, Pokrivcak, Toth ve Plevny, 2017) eve teslimat için ödeme yapma istekleri, diğer ürün gruplarına kıyasla daha düşüktür (Teller, Kotzab ve Grant, 2006). Ayrıca sanal market alışverişlerinde fiyatların görece daha yüksek olarak belirlenmesi de (Singh ve Rosengren, 2020) finansal risk algısını arttırmaktadır. Bu sebeple aşağıdaki hipotez geliştirilerek, \%95 güven düzeyinde test edilmiştir

H9: Finansal riskin sanal market alışverişi yapma niyeti üzerinde negatif yönlü etkisi vardır.

\section{Zaman Riski}

Zaman riski, tüketicilerin alışveriş sürecinde zaman kaybı yaşayabileceklerine ilişkin endişeleridir (Roselius, 1971). Çevrimiçi alışveriş mağazaya gitme, kasada sıra bekleme gibi süreçleri ortadan kaldırarak zamandan tasarruf edilmesini sağlasa da, hızlı tüketim ürünlerine hemen ulaşma isteği tüketicinin algıladığı zaman riskini artırabilir (Seitz ve diğerleri, 2017; Verhoef ve Langerak, 2001). Sanal market alışverişi alternatiflerini belirleme, uygun olanı seçme, alışveriş yapma, ürünlerin teslimatını bekleme ve olası iade işlemlerini gerçekleştirme süreçlerinin zaman alacağına yönelik endişeler, zaman riskini artırabilir (Ha, 2002; McCorkle,1990). Bu sebeple aşağıdaki hipotez geliştirilerek, \%95 güven düzeyinde test edilmiştir

$\mathbf{H}_{10}$ : Zaman riskinin sanal market alışverişi yapma niyeti üzerinde negatif yönlü etkisi vardır.

\section{Fiziksel Risk}

Fiziksel risk, tüketicinin ürün ya da hizmeti satın alması sonucunda sağlığına zarar verebileceğine yönelik endişeleridir (Hassan ve diğerleri, 2006). Tüketiciler diğer ürün gruplarına kıyasla gıda alışverişlerinde daha seçici, şüpheci ve temkinli davranmaktadır. Sanal market alışverişine konu olan ürünlerin başkası tarafından seçilmesi ürünün tazeliği, bozulmuş olması gibi endişelere neden olabilir. Ürünlerin dağıtım aşamasında uygun sıcaklık ortamında ve sağlığa uygun koşullarda taşınmaması gibi kalite standartları ile ilgili endişeler de fiziksel risk algılarını arttırabilir (Seitz ve diğerleri, 2017). Bu sebeple aşağıdaki hipotez geliştirilerek, \%95 güven düzeyinde test edilmiştir

H11: Fiziksel riskin sanal market alışverişi yapma niyeti üzerinde negatif yönlü etkisi vardır. 


\section{Psikolojik Risk}

Psikolojik risk, ürünün satın alınma düşüncesinin tüketicide stres yaratmasıdır (Jacoby ve Kaplan, 1972). Sanal market alışverişinde ürünlerin görülmeden ve dokunulmadan internet üzerinden satın alınması tüketiciler için başlıca stres kaynağı oluştururken, ürünlerin başkası tarafından seçiliyor olması da iğrenme duygusuna sebep olabilir (Argo, Dahl ve Morales, 2006). Dolayısıyla sanal market alışverişlerinde psikolojik riskin alışveriş yapma niyeti üzerinde negatif yönlü etkili olması beklenmektedir. Bu sebeple aşağıdaki hipotez geliştirilerek, \%95 güven düzeyinde test edilmiştir

H12: Psikolojik riskin sanal market alışverişi yapma niyeti üzerinde negatif yönlü etkisi vardir.

\section{Sosyal Risk}

Sosyal risk, tüketicinin bir ürünü satın alımı sonucunda kendisi ile ilgili toplumda olumsuz düşüncelerin oluşmasına yönelik endişeleridir (Hassan ve diğerleri, 2006). Bunun yanı sıra sosyal risk, tüketicinin sosyalleşmesini engelleyen durumlar karşısında da algılanabilmektedir. Fiziksel kanallardan alışveriş yapmayı sosyalleşme aracı olarak gören tüketici, bu kanallara yönelik sosyal risk algılayabilir (Berg ve Henriksson, 2020). Bu sebeple sosyal riskin sanal market alışverişi yapma niyeti üzerinde negatif yönlü etkisinin olması beklenmektedir. Bu sebeple aşağıdaki hipotez geliştirilerek, \%95 güven düzeyinde test edilmiştir.

H13: Sosyal riskin sanal market alışverişi yapma niyeti üzerinde negatif yönlü etkisi vardır.

\section{Araştırma Modeli}

\section{Yöntem}

Tüketicilerin sanal market alışverişini benimsemelerinde etkili olan faktörlerin incelenmesi amacı ile çalışmanın kavramsal çerçevesi Genişletilmiş Teknoloji Kabul Modeli2 (UTAUT2)'ye dayanmaktadır. Sanal market alışverişinin önündeki engellerin tespiti için ise, UTAUT2 modeline risk algısı faktörleri dahil edilmiştir. Bu kapsamda oluşturulan çalışmanın teorik modeli Şekil 1'de gösterildiği gibidir. 


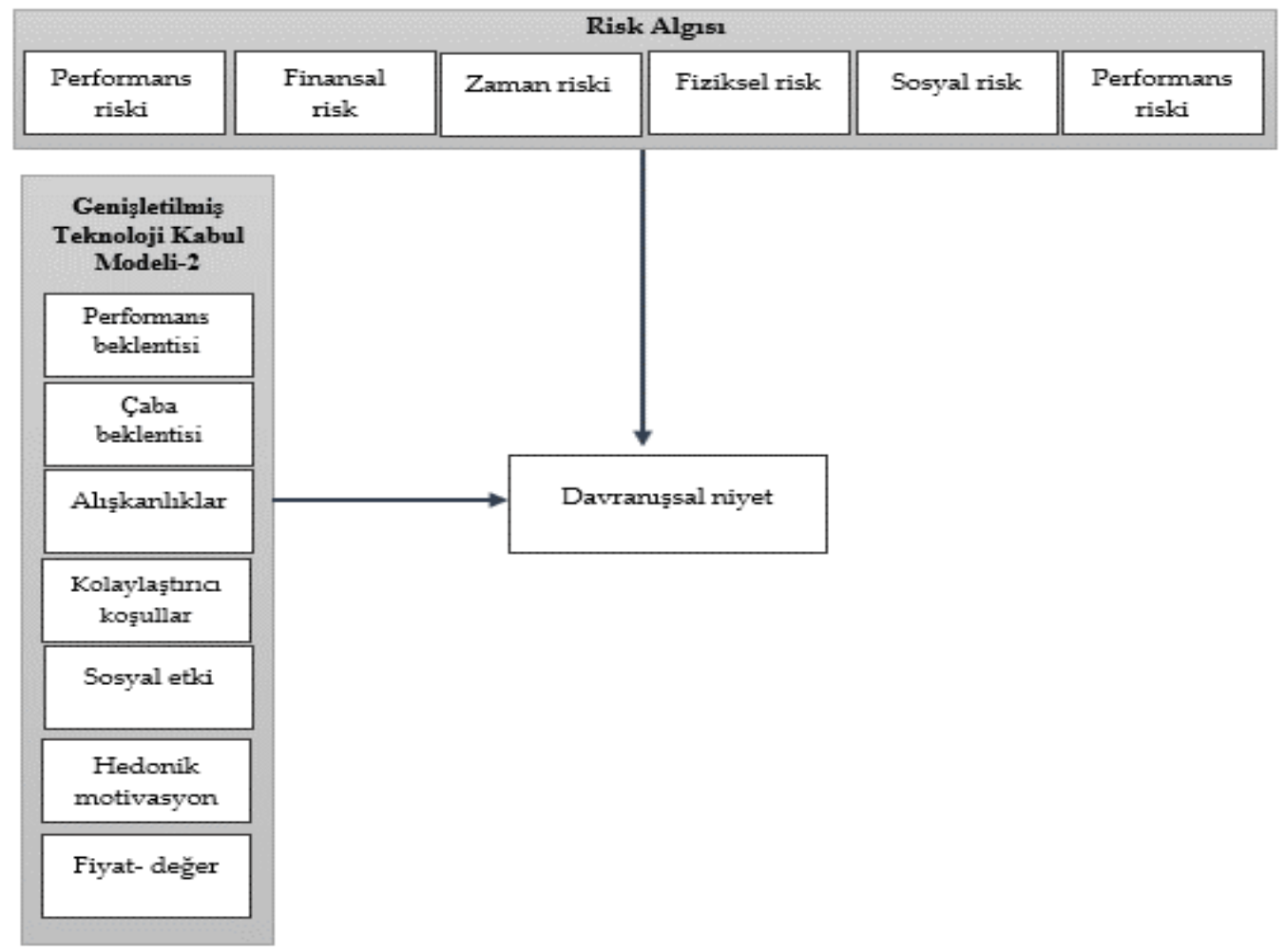

\section{Evren ve Örneklem}

Şekil 1. Araştırmanın kavramsal modeli

Veriler tesadüfi olmayan örnekleme yöntemlerinden, kolayda örnekleme yöntemi kullanılarak toplanmıştır. Risk algıları ve alışveriş niyetine ilişkin sorular sanal market alışverişini hem yapan hem de yapmayan katılımcılara uygulanmıştır. Böylece mevcut müşterilerin yanı sıra potansiyel müşterilerin de bu kanallara ilişkin risk algıları tespit edilerek, pazarın büyümesi için veri sağlanması amaçlanmıştır. UTAUT2 ölçek soruları ise, deneyime bağlı olarak cevaplanabilecek ifadeleri içermesinden dolayı en az bir kere sanal market alışverişi yapan katılımcılara uygulanmıştır. Bu koşullar doğrultusunda 421 kişiye anket uygulanmış olup, toplanan anketlerden 19'unun hatalı, eksik ya da gelişigüzel doldurulması sebebi ile araştırma kapsamından çıkarılmasına karar verilmiştir. Böylece örneklem hacmi 402 olarak kesinleşmiştir.

\section{Veri Toplama Araci}

Araştırma kapsamında kullanılan veriler Eylül- Aralık 2019 tarihleri arasında çevrimiçi anket formu vasıtasıyla toplanmıştır. Ankette yer alan risk algılarına ilişkin ifadeler Hassan ve diğerleri (2006) tarafından geliştirilen risk algısı ölçeğinden; sanal market alışverişinin benimsenmesinde etkili olan ifadeler Venkatesh ve diğerleri (2012) tarafından geliştirilen UTAUT2 ölçeğinden ve alışveriş yapma niyetine ilişkin ifadeler Bambauer-Sachse ve Mangold (2011), Gefen ve Straub (2004), Hwang, Yoon ve Park (2011) çalışmalarından yararlanılarak oluşturulmuş olup, bu ifadeler likert ölçek (1=Kesinlikle katılmıyorum 5=Kesinlikle katılıyorum) kullanılarak hazırlanmıştır. Anket sorularının anlaşılırlığının test edilmesi amacı ile kolayda örnekleme yöntemi ile 30 kişiye ön test uygulanmıştır. Anket formuna nihai şeklinin verilmesinin ardından, Aralık 2019'da toplanan verilerin analizinde SPSS 20.0 paket programı kullanılmıştır. 


\section{Bulgular}

Demografik profil incelendiğinde (Tablo 1) katılımcıların çoğunluğu kadın, bekar, 2001-4000 TL aylık hane gelirine sahip, özel sektör çalışanı, lisans mezunu, 26-35 yaş grubunda ve çocuk sahibi değildir.

Tablo 1. Katılımcıların Demografik Profili

\begin{tabular}{|c|c|c|c|c|c|}
\hline Cinsiyet & Frekans & $\%$ & Medeni Durum & Frekans & $\%$ \\
\hline Kadın & 231 & 57,5 & Evli & 131 & 32,6 \\
\hline Erkek & 172 & 42,5 & Bekar & 271 & 67,4 \\
\hline Gelir düzeyi & Frekans & $\%$ & Meşguliyet & Frekans & $\%$ \\
\hline 2000 TL ve altı & 38 & 9,5 & Kamu çalışanı & 78 & 19,4 \\
\hline 2001-4000 TL & 99 & 25,4 & Özel sektör & 135 & 33,6 \\
\hline 4001-6000 TL & 90 & 22,0 & Öğrenci & 95 & 23,6 \\
\hline 6001-8000 TL & 57 & 14,4 & Serbest meslek & 39 & 9,7 \\
\hline 8001- 10000 TL & 57 & 14,2 & Ev hanımı & 15 & 3,7 \\
\hline 10001 TL ve üzeri & 61 & 15,2 & Çalışmıyor & 40 & 10,0 \\
\hline Eğitim Düzeyi & Frekans & $\%$ & Yaş & Frekans & $\%$ \\
\hline Lise mezunu & 64 & 15,9 & $18-25$ & 139 & 34,6 \\
\hline Ön lisans mezunu & 23 & 5,7 & $26-35$ & 156 & 38,8 \\
\hline Lisans mezunu & 182 & 45,3 & $36-41$ & 74 & 18,4 \\
\hline Lisansüstü mezunu & 133 & 33,1 & 42 ve üzeri & 33 & 8,2 \\
\hline Çocuk Sayısı & Frekans & $\%$ & & & \\
\hline Yok & 313 & 77,9 & & & \\
\hline 1 & 61 & 15,2 & & & \\
\hline 2 ve daha fazla & 28 & 6,9 & & & \\
\hline
\end{tabular}

Örneklemin \%96,5'ini oluşturan 388 katılımcı internet üzerinden alışveriş yaparken, market alışverişini internet üzerinden yapan katılımcıların oranı \%67,9'dur. Sanal market alışverişi için en fazla tercih edilen site ve uygulamalar sırasıyla Migros Sanal Market, Hepsiburada.com ve n11.com'dur. Bu kanallardan yapılan alışverişlerde en fazla satın alınan ürünlerin deterjan ve temizlik ürünleri olduğu; en az tercih edilenlerin ise et, balık ve kümes ürünleri ile meyve ve sebze olduğu belirlenmiştir. 
Genişletilmiş Teknoloji Kabul Modeli Bileşenleri ile Risk Algılarının Sanal Market Alışverişi Yapma Niyeti Üzerindeki Etkisi

Tablo 2. Sanal Market Alışverişi Yapma Alışkanlıkları

\begin{tabular}{|c|c|c|c|c|c|}
\hline Ürün Kategorisi & $\begin{array}{c}\text { Satın Alan } \\
\text { Kişi Frekansı }\end{array}$ & $\begin{array}{c}\text { Satın } \\
\text { Alan } \\
\text { Yüzdesi } \\
\end{array}$ & Ürün kategorisi & $\begin{array}{c}\text { Satın Alan } \\
\text { Kişi } \\
\text { Frekansı } \\
\end{array}$ & $\begin{array}{l}\text { Satın Alan } \\
\text { Yüzdesi }\end{array}$ \\
\hline Hiçbiri & 145 & 36,1 & İçecek & 139 & 34,6 \\
\hline $\begin{array}{l}\text { Deterjan ve } \\
\text { temizlik }\end{array}$ & 183 & 45,5 & Meyve ve sebze & 91 & 22,6 \\
\hline $\begin{array}{c}\text { Et, balık ve kümes } \\
\text { ürünleri }\end{array}$ & 57 & 14,2 & $\begin{array}{c}\text { Süt ve } \\
\text { kahvaltılık }\end{array}$ & 114 & 28,4 \\
\hline Gida ve şekerleme & 151 & 37,6 & $\begin{array}{l}\text { Tuvalet kâğıdı } \\
\text { ve havlu kağıt }\end{array}$ & 140 & 34,8 \\
\hline
\end{tabular}

Araştırmada kullanılan UTAUT2, risk algısı ve satın alma niyeti sorularının Skewness ve Kurtosis değerlerinin +1,5/-1,5 arasında olması (Tabachnick ve Fidell, 2015) sebebi ile ifadelerin normallik koşullarını sağladığı tespit edilmiştir. Normallik testinin ardından yapı geçerliliğinin test edilmesi amacı ile Varimax rotasyonlu açıklayıcı faktör analizi uygulanmış ve içsel tutarlılığın test edilmesine yönelik Cronbach alpha katsayıları hesaplanmıştır. UTAUT2 ifadelerine ilişkin gerçekleştirilen faktör analizinde (Tablo 3) düşük faktör yükü ve çapraz faktör yüklerindeki sorunlar nedeni ile sırasıyla kolaylaştırıcı unsurlar, alışkanlık ve sosyal etki boyutlarından birer madde araştırma kapsamından çıkarılmıştır. Sadece iki maddeden oluşan sosyal etki boyutunun Cronbach alpha düzeyinin $(0,58)$ düşük olmasına karşın, soru sayısının daha fazla azaltılmaması adına analizden çıkarılmamasına karar verilmiştir.

Tablo 3. UTAUT2 Ölçeğine İlişkin İfadelerin Faktör Analizi

\begin{tabular}{lc}
\hline UTAUT2 Ölçeğine İlişkin İfadeler $(\mathrm{KMO}=0,856$ Bartlett=4012,021 p=0,000) & $\begin{array}{c}\text { Faktör } \\
\text { Yükleri }\end{array}$ \\
\hline Çaba Beklentisi (Açılanan Varyans = 36,846 Cronbach alpha= 0,901) &, 810 \\
\hline Market alışverişimi internet üzerinden yapmayı öğrenmek benim için kolaydır. &, 801 \\
Market alışverişimi internet üzerinden yapmak açık ve anlaşılırdır. &, 790 \\
Market alışverişimi internet üzerinden gerçekleştirecek yetenekleri elde etmek benim için &, 750 \\
kolaydır. &, 898 \\
Market alışverişimi internet üzerinden gerçekleştirmek benim için kolaydır. &, 893 \\
\hline Hedonik Motivasyon (Açıklanan Varyans = 15,281 Cronbach alpha=0,925) &, 790 \\
\hline İnternet üzerinden market alışverişi yapmak keyiflidir & İnternet üzerinden market alışverişi yapmak eğlencelidir \\
İnternet üzerinden market alışverişi yapmak ilgi çekicidir.
\end{tabular}

Alışkanlık (Açıklanan Varyans=7,633 Cronbach alpha= 0,873)

Market alışverişimi internet üzerinden yapmak benim için sıradan bir aktivite haline geldi. 
Market alışverişimi her zaman internet üzerinden yapmak benim için alışkanlık haline geldi.

Market alışverişimi her zaman internet üzerinden yapmayı tercih ederim.

Kolaylaştırıcı Unsurlar (Açıklanan Varyans=6,721 Cronbach alpha= 0,927)

Market alışverişimi internet üzerinden yapmak için gerekli olan teknolojik bilgiye sahibim

Market alışverişimi internet üzerinden yapmak için gerekli teknolojik donanıma (telefon, internet vb.) sahibim.

Market alışverişimi internet üzerinden yapmak kullandığım teknolojiler ile uyumludur.

Fiyat- Değer (Açılanan Varyans= 5,779 Cronbach alpha= 0,842)

Market alışverişimi internet üzerinden yapmak uygun fiyatlıdır.

Market alışverişimi internet üzerinden yaptığımda, harcadığım paranın karşıllğını aliyorum.

Mevcut fiyatlara göre, internet üzerinden market alışverişi yapılması iyi bir hizmettir.

Performans Beklentisi (Açılanan Varyans= 5,025 Cronbach alpha= 0,807)

Market alışverişimi internet üzerinden yapmak, daha fazla ürün çeşitliliğini görmeme yardımcı olur.

Market alı̧verişimi internet üzerinden yapmak, verimliliğimi artırır.

Market alışverişimi internet üzerinden yapmak alışverişimi daha hızlı bir şekilde gerçekleştirmemi sağlar.

Sosyal Etki (Açılanan Varyans= 3,542 Cronbach alpha= 0,589)

Çevremdeki insanların market alışverişlerini internet üzerinden yapmaları, benim de yapmamda etkili olur.

Market alı̧̧verişini internet üzerinden yapmak çevremde trend haline geldi.

Risk algısı ifadelerine yönelik uygulanan faktör analizinde (Tablo 4) finansal risk boyutunda yer alan bir ifadenin zaman riski boyutu içerisinde yer aldığ tespit edilmiş olup, analizden çıkarılmasına karar verilmiştir.

Tablo 4. Risk Algısı Ölçeğine İlişkin Faktör Analizi

Risk Algısı Ölçeğine İlişkin İfadeler (KMO 0,848 Bartlett 3609,563 p=0,00)

Faktör

Yükleri

Performans Riski (Açılanan Varyans= 36, 727 Cronbach alpha= 0,885)

İnternet üzerinden market alışverişi yapmam durumunda ürünlerin görselde görülenden farklı çıkmasından endişelenirim.

Market alışverişimi internet üzerinden yaptığımda ürünlerin beklediğimden kalitesiz çıkmasından endişelenirim.

Market alş̧verişimi internet üzerinden yaparken ürünleri görememek, dokunup, inceleyememek benim için sorundur.

Sosyal Risk (Açıklanan Varyans= 16, 689 Cronbach alpha $=, 850$ ) 
Market alışverişimi internet üzerinden yaparak arkadaşlarım tarafından daha havalı görüneceğimi düşünürüm.

Market alışverişimi internet üzerinden yaparsam arkadaşlarım tarafından daha fazla

saygı göreceğime inanırım.

Market alışverişimi internet üzerinden yaparsam bazı arkadaşlarım gösteriş yapmaya çalıştı̆̆ımı düşünür.

Zaman Riski (Açıklanan Varyans= 7,999 Cronbach alpha= ,833)

İnternet üzerinden satın aldığım market ürünlerinin zamanında teslim edilemeyeceğinden endişelenirim.

İnternet üzerinden satın aldığım market ürünlerinin iadesinin zaman alacağını düşünürüm.

Market alışverişimi internet üzerinden yaparsam ürünleri sipariş etme ve teslim alma sürecinin uzun olmasından endișelenirim.

Psikolojik Risk (Açıklanan Varyans= 7,381 Cronbach alpha= ,773)

Market alışverişimi internet üzerinden yapma düşüncesi beni rahatsız ediyor.

Market alışverişimi internet üzerinden yapma düşüncesi beni geriyor.

Market alışverişimi internet üzerinden yapmanın sosyalleşmemi engelleyeceğini düşürüm.

Finansal Risk (Açıklanan Varyans= 6,050 Cronbach alpha= ,912)

İnternet üzerinden market alışverişi yapmam durumunda kredi kartı bilgilerimi vermeyi güvenli bulmuyorum.

Market alışverişimi internet üzerinden yapmam durumunda kart bilgilerimin paylaşılması sonucu parasal kayıplara uğrayabileceğimden endişelenirim.

Fiziksel Risk (Açıklanan Varyans= 4,705 Cronbach alpha $=$,748)

Market alışverişimi internet üzerinden yapmam durumunda bilgisayar ekranına sık sık maruz kalmam sebebi ile göz yorgunluğu yaşamaktan endişelenirim.

Market alışverişimi internet üzerinden yaparken, durumunda bilgisayarıma virüs bulaşmasından endişelenirim.

Sanal market alışverişi yapma niyetlerine ilişkin faktör analizi sonuçları (Tablo 5) incelendiğinde ifadelerin tek bir faktör altında toplanarak, toplam varyanstaki değişimin $\% 85,06$ 'sını açıkladığ görülmektedir.

Tablo 5. Sanal Market Alışverişi Yapma Niyetine İlişkin Faktör Analizi

\begin{tabular}{lc}
\hline Alışveriş Yapma Niyetine İlişkin İfadeler $(\mathrm{KMO}=, 743$ Bartlett= 842,204 Açılanan & \\
Varyans= 85,06 Cronbach alpha=,911) &, 942 \\
\hline Market alışverişimi internet üzerinden yapma ihtimalim yüksektir. &, 914 \\
Market alışverişimi internet üzerinden yapabilirim. &, 910 \\
Market alışverişlerini internet üzerinden yapmalarını çevreme önerebilirim.
\end{tabular}

Katılımclar sanal market alışverişi yapma niyeti ifadelerine katılım derecelerinin ortalamaları baz alınarak üç gruba ayrılmıştır. Boyut ortalaması 1 (kesinlikle katılmıyorum) 
ve 2 (katılmıyorum) olan katılımcılar $(\mathrm{n}=88$ ) alışveriş yapma niyeti düşük, 3 (ne katılıyorum ne katılmıyorum) olan katılımclar (n=99) orta ve 4 (katılıyorum) ve 5 (kesinlikle katıliyorum) olan katılımcılar ( $n=221$ ) yüksek olmak üzere gruplandırılmış olup, gruplar arasında sanal market alışverişine yönelik risk algılarına ilişkin farklılıklar incelenmiştir. Tablo 6'da sonuçları gösterilen analize göre, sosyal risk dışındaki bütün risk algılarında gruplar arasında anlamlı farklılık bulunmaktadır. Bunun yanı sıra sanal market alışverişi yapma niyeti düşük olan katılımcılar bütün risk algılarını daha yoğun hissetmektedir.

Tablo 6. Risk Algılarının Alışveriş Yapma Niyetine Göre Farklılıkları

\begin{tabular}{|c|c|c|c|c|}
\hline & Alışveriş Yapma Niyeti & $\begin{array}{c}\text { Risk Algısı } \\
\text { Ortalamaları }\end{array}$ & $\mathbf{F}$ & $\mathbf{p}$ \\
\hline \multirow{3}{*}{$\begin{array}{l}\text { Performans } \\
\text { riski }\end{array}$} & Düşük & 3,9228 & & \\
\hline & Orta & 3,2525 & 39,837 & ,000 \\
\hline & Yüksek & 2,6139 & & \\
\hline \multirow{3}{*}{ Zaman riski } & Düşük & 3,7154 & & \\
\hline & Orta & 3,3771 & 9,263 & ,000 \\
\hline & Yüksek & 3,0814 & & \\
\hline \multirow{3}{*}{ Psikolojik risk } & Düşük & 2,4024 & & \\
\hline & Orta & 1,7811 & 46,363 & ,000 \\
\hline & Yüksek & 1,3741 & & \\
\hline \multirow{3}{*}{ Finansal risk } & Düşük & 3,0854 & & \\
\hline & Orta & 2,7828 & 12,162 & ,000 \\
\hline & Yüksek & 2,2986 & & \\
\hline \multirow{3}{*}{ Fiziksel risk } & Düşük & 2,0183 & & \\
\hline & Orta & 1,7172 & 5,244 & ,006 \\
\hline & Yüksek & 1,6041 & & \\
\hline
\end{tabular}

UTAUT2 ile risk algılarının alışveriş yapma niyeti üzerine etkisinin incelenmesine yönelik, çoklu doğrusal regresyon analizinin uygulanmasına karar verilmiştir. Çoklu doğrusal regresyon analizi bir değişkenin (bağımlı) birden fazla değişken (bağımsız) tarafından açıklanma düzeyi ile ilişkinin yönünün yorumlanmasına imkan vermektedir. Bu özellikleri itibari ile sosyal bilimlerde kullanılan en yaygın ve kullanışlı yöntemler arasında gösterilmektedir (Durmuş ve diğerleri, 2016; Gegez, 2015).

Regresyon analizinin uygulanmasından önce bağımsız değişkenler arasında çoklu bağıntı probleminin olup olmadığının tespit edilmesi amacı ile korelasyon katsayıları incelenmiştir. Bağımsız değişkenler arasındaki korelasyon düzeyleri incelendiğinde (Tablo 7), UTAUT2 değişkenlerinden fiyat/değer ile risk algılarından finansal risk arasında yüksek korelasyonun bulunduğu görülmektedir (\%89). Çoklu bağıntı probleminin daha detaylı tespiti ve hangi 
boyutun analiz kapsamından çıkarılacağına karar verilmesi için VIF (varyans şişme faktörü) ve Durbin-Watson katsayılarının incelenmesine karar verilmiştir.

Tablo 8 incelendiğinde finansal risk değişkeninin VIF değerinin kabul edilebilir değerin üstünde $(10,280)$ olması nedeni ile analizden çıkarılmasına karar verilmiştir. Son durumda ise Durbin-Watson katsayısı 1,903 olup, kabul edilebilir değerin $(2,5)$ altında olması sebebi ile regresyon analizinin uygulanması için ön koşulların sağlandığı görülmektedir.

Regresyon analizi sonuçları incelendiğinde, modelin sanal market alışverişi yapma niyetini \%41 oranında açıladığ1 görülmektedir. UTAUT2 değişkenlerinin alışveriş yapma niyeti üzerindeki etkisinin anlamlılık düzeyleri incelendiğinde kolaylaştırıcı unsurların $(p=0,004)$, performans beklentisinin $(p=0,001)$ ve alışkanlığın $(p=0,000)$ pozitif yönlü bir etkisinin olduğu görülmektedir. Bu sebeple $\mathrm{H}_{1}, \mathrm{H}_{4}$ ve $\mathrm{H}_{7}$ hipotezleri desteklenmiştir. Diğer taraftan çaba beklentisi, hedonik motivasyonlar, fiyat-değer ve sosyal etkinin alışveriş yapma niyeti üzerindeki etkisi anlamlı değildir. Dolayısıyla $\mathrm{H}_{2}, \mathrm{H}_{3}, \mathrm{H}_{5}, \mathrm{H}_{6}$ hipotezleri reddedilmiştir.

Risk algısına ilişkin boyutlar incelendiğinde alışveriş yapma niyeti üzerinde psikolojik riskin ( $\mathrm{p}=0,007)$ negatif yönlü ve zaman riskinin $(\mathrm{p}=0,008)$ pozitif yönlü etkisinin olduğu tespit edilmiştir. $\mathrm{Bu}$ sebeple $\mathrm{H}_{12}$ hipotezi desteklenirken, $\mathrm{H}_{10}$ hipotezi reddedilmiştir. Diğer taraftan performans riski ile finansal, fiziksel ve sosyal riskin alışveriş yapma niyeti üzerinde anlamlı etkisinin tespit edilmemiş olmasından dolayı $\mathrm{H}_{8}, \mathrm{H}_{9}, \mathrm{H}_{11}$ ve $\mathrm{H}_{13}$ hipotezleri reddedilmiştir. 
Çakır \& Kazançoğlu

Tablo 7. UTAUT2 ve Risk Algısı Değişkenlerinin Alışveriş Yapma Niyeti ile İlişkisi

\begin{tabular}{|c|c|c|c|c|c|c|c|c|c|c|c|c|c|}
\hline & Niyet & 1 & 2 & 3 & 4 & 5 & 6 & 7 & 8 & 9 & 10 & 11 & 12 \\
\hline 1.Çaba & $427^{* *}$ & & & & & & & & & & & & \\
\hline 2.Hedonik &, $365^{* *}$ &, $324^{* *}$ & & & & & & & & & & & \\
\hline 3.Alışkanlık &, $421^{* *}$ & $241^{* *}$ & $450^{* *}$ & & & & & & & & & & \\
\hline 4.Kolaylaştırıcı &, $427^{* *}$ &, $704^{* *}$ &, $316^{* *}$ & 115 & & & & & & & & & \\
\hline 5.Fiyat-değer &,$- 282^{* *}$ &,$- 143^{*}$ &,$- 140^{*}$ &,$- 203^{* *}$ &,- 048 & & & & & & & & \\
\hline 6.Performans beklentisi & $486^{* *}$ &, $544^{* *}$ &, $510^{* *}$ &, $434^{* *}$ &, $388^{* *}$ &,- 121 & & & & & & & \\
\hline 7.Sosyal etki & 061 & ,009 &, $212^{* *}$ &, $253^{* *}$ &,- 032 & ,061 & ,106 & & & & & & \\
\hline 8.Performans riski &,$- 460^{* *}$ &,$- 130^{*}$ &,$- 177^{*}$ &,$- 250^{* *}$ &,- 032 &, $532^{* *}$ &,$- 148^{*}$ &,- 004 & & & & & \\
\hline 9.Zaman riski &,$- 249^{* *}$ &,- 069 &,- 111 &,$- 237^{* *}$ & ,008 &, $583^{* *}$ &,- 079 & 041 &, $588^{* *}$ & & & & \\
\hline 10.Psikolojik risk &,$- 525^{* *}$ &,$- 314^{* *}$ &,$- 196^{* *}$ &,$- 160^{* *}$ &,$- 380^{* *}$ &, $396^{* *}$ &,$- 179^{* *}$ & $152^{*}$ &, $467^{* *}$ &, $363^{* *}$ & & & \\
\hline 11.Finansal risk &,$- 289^{* *}$ &,$- 177^{* *}$ &,$- 137^{*}$ &,$- 172^{* *}$ &,- 105 &, $939 * *$ &,$- 141^{*}$ & ,059 &, $483^{* *}$ &, $462^{* *}$ &, $385^{* *}$ & & \\
\hline 12.Fiziksel risk &,$- 266^{* *}$ &,$- 241^{* *}$ &,- 045 &,- 026 &,$- 266^{* *}$ &, $508^{* *}$ &,- 037 &, $210^{* *}$ &, $333^{* *}$ &, $376^{* *}$ &, $483^{* *}$ &, $505^{* *}$ & \\
\hline 13.Sosyal risk & 044 &,$- 155^{*}$ & ,025 & ,011 &,- 198 &, $138^{* *}$ & ,030 &, $256^{* *}$ &,- 029 & ,016 & $272^{* *}$ &, $157^{* *}$ &, $311^{* *}$ \\
\hline
\end{tabular}

Sayfa 319 | 2020; 18 (2); Beşerî Bilimler Sayısı / İktisadi İdari Bilimler Sayısı 
Tablo 8. Sanal Market Alışverişinin Benimsenmesinde Etkili Olan Faktörler ile Risk Algılarının Alışveriş Yapma Niyeti Üzerindeki Etkisi

\begin{tabular}{|c|c|c|c|c|c|c|c|}
\hline \multirow{2}{*}{$\begin{array}{c}\text { Bağımsız } \\
\text { Değişken: UTAUT2 } \\
\text { (F=21,156 p=0,000 } \\
\left.R^{2}=0,367\right)\end{array}$} & \multicolumn{2}{|c|}{$\begin{array}{l}\text { Standardize } \\
\text { Olmayan } \\
\text { Katsayilar }\end{array}$} & \multirow{2}{*}{$\begin{array}{c}\text { Standardize } \\
\text { Katsayılar } \\
\text { Beta }\end{array}$} & \multirow[t]{2}{*}{$\mathbf{t}$} & \multirow[t]{2}{*}{ p } & \multicolumn{2}{|c|}{$\begin{array}{c}\text { Doğrusal bağlantı } \\
\text { istatistikleri }\end{array}$} \\
\hline & B & $\begin{array}{l}\text { Std. } \\
\text { Hata }\end{array}$ & & & & Tolerans & VIF \\
\hline (Sabit) & ,775 & 479 & & 1,620 & 0,107 & & \\
\hline Çaba beklentisi & 0,040 & 0,107 & 0,029 & 0,379 & 0,705 & 0,406 & 2,464 \\
\hline $\begin{array}{c}\text { Hedonik } \\
\text { motivasyonlar }\end{array}$ & 0,017 & 0,052 & 0,020 & 0,327 & 0,744 & 0,631 & 1,584 \\
\hline Alışkanlık & 0,219 & 0,047 & 0,280 & 4,677 & 0,000 & 0,658 & 1,519 \\
\hline $\begin{array}{l}\text { Kolaylaştırıcı } \\
\text { unsurlar }\end{array}$ & 0,332 & 0,116 & 0,212 & 2,868 & 0,004 & 0,433 & 2,307 \\
\hline Fiyat-değer & 0,024 & 0,055 & 0,030 & 0,438 & 0,662 & 0,491 & 2,038 \\
\hline $\begin{array}{l}\text { Performans } \\
\text { beklentisi }\end{array}$ & 0,224 & 0,066 & 0,226 & 3,388 & 0,001 & 0,531 & 1,882 \\
\hline Sosyal etki &,- 019 & 0,046 & $-, 0,023$ & $-0,424$ & 0,672 & 0,828 & 1,208 \\
\hline Performans riski & $-0,082$ & 0,054 & $-0,100$ & $-1,515$ & 0,131 & 0,540 & 1,852 \\
\hline Zaman riski & 0,134 & 0,050 & 0,172 & 2,691 & 0,008 & 0,578 & 1,729 \\
\hline Psikolojik risk & $-0,228$ & 0,084 & $-0,174$ & $-2,727$ & 0,007 & 0,583 & 1,716 \\
\hline Fiziksel risk & $-0,051$ & 0,065 & $-0,051$ & $-0,794$ & 0,428 & 0,569 & 1,758 \\
\hline Sosyal risk & 0,092 & 0,067 & 0,075 & 1,361 & 0,175 & 0,773 & 1,294 \\
\hline
\end{tabular}

\section{Tartışma, Sonuç ve Öneriler}

İnternet ve mobil teknolojilerin kullanımının yaygınlaşması tüketicilerin hayatlarının pek çok noktasında olduğu gibi alışveriş deneyimlerinde de değişiklik yaratmış ve e-perakende uygulamaları hızla benimsenmiştir. Fakat hızlı tüketim ürünlerinin satışa sunulduğu sanal market alışverişlerinin, tüketiciler tarafından benimsenme oranları çok daha yavaş artış göstermektedir (Gore, 2017; Kureshi ve Thomas, 2019; Weber ve Badenhorst-Weiss, 2018). Sanal market alışverişinin kullanım oranlarının arttırılması ve gelişmekte olan pazar yapısına veri sağlanabilmesi için, bu çalışmada sanal market alışverişinin benimsenmesinde etkili olan faktörler ile risk algılarının alışveriş yapma niyeti üzerindeki etkisi incelenmiştir. Çalışmada katılımcıların büyük bir kısmının internet üzerinden alışveriş yaptığı, fakat sanal market alışverişi yapma tercihleri incelendiğinde bu oranın daha düşük olduğu tespit edilmiştir. Araştırma modeline risk algılarının dahil edilmesi, bu kanalların benimsenme hızının düşük olma nedenlerine ışık tutulmasını sağlamıştır. Tüketiciler sanal market alışverişlerinde deterjan ve temizlik ürünleri gibi standart kaliteye sahip olan ve ağırlık bakımından taşınması zor olan ürünleri daha fazla tercih etme eğilimindedir. Diğer taraftan ambalajlı hızlı tüketim ürünlerinden farklı olarak et, balık, kümes ürünleri ile meyve ve 
sebze gibi standart kalitenin yakalanmasının zor olduğu ürünlerin seçiminde aktif rol oynamak istemektedirler. Sanal market alışverişlerinde en fazla tercih edilen site ve uygulamaların Migros Sanal Market, Hepsiburada.com ve n11.com olduğu göz önünde bulundurulduğunda ise, tüketicilerin kanal seçimlerinde güvenin ve daha fazla noktaya teslimat gerçekleştirebilme yeteneğinin belirleyici bir rol oynadığı söylenebilir.

Alışveriş yapma niyetlerine göre risk algısı düzeyleri incelendiğinde performans ve zaman riski ile psikolojik, finansal, fiziksel risk algılarının alışveriş yapma niyeti düşük olan katılımcılarda yüksek algılandığı bulgusu elde edilmiştir. Dolayısıyla sanal market alışverişi yapma niyeti düşük olan katılımcılar kalitesiz, bozulmuş ve sağlıksız ürünlerin gönderilmesinden endişelenmekle birlikte, ürünlerin seçiminde aktif rol oynayamamaları sebebi ile psikolojik olarak gerilim hissetmektedirler. Ayrıca bu tüketiciler iade ve alışveriş süreçlerinin fiziksel kanallara kıyasla daha fazla zaman alacağını ve lojistik ile ilgili maliyetlerden kaynaklı olarak daha fazla finansal kayba uğrayacaklarını düşünmektedirler. Sanal market alışverişi yapma niyeti düşük olan katılımcılar bütün risk algılarını daha yüksek algılasalar da, algıladıkları en yoğun risk performans riskidir. Elde edilen bu bulgu literatürdeki diğer çalışmaları destekler niteliktedir (Martinez ve diğerleri, 2018; Rogus, Guthrie, Niculescu ve Mancino, 2019; Singh ve Rosengren, 2020).

Alışveriş yapma niyeti bakımından oluşturulan gruplar arasında sadece sosyal risk bakımından anlamlı farklılık tespit edilmemiştir. Sanal market alışverişine yönelik sosyal risk algısını inceleyen çalışmalarda Rogus ve diğerleri (2019), sanal market alışverişinin tüketicinin evden alışveriş yaparak sosyalleşmesini engellediğini savunurken, Berg ve Henriksson (2020) sanal market alışverişi ile elde edilen zaman tasarrufunun aile ya da arkadaşlara ayrılabileceğini bu sebeple bu kanallara ilişkin tüketicinin sosyal risk algılamadığını ileri sürmektedir. Bu çalışmada katılımcılarda iki farklı görüşün hakim olmasından dolayı gruplar arasında anlamlı farklılık tespit edilmemiş olabilir.

Sanal market alışverişinin benimsenmesinde etkili olan faktörlerin alışveriş yapma niyetindeki etkisi ile ilgili elde edilen bulgular kolaylaştırıcı unsurların (An, Tong ve Han, 2016; Berg ve Henriksson, 2020; Tak ve Panwar, 2017), alışkanlığın (Singh ve Matsui, 2017; Tak ve Panwar, 2017) ve performans beklentisinin (An ve diğerleri, 2016; Berg ve Henriksson, 2020; Singh ve Matsui, 2017; Tandon ve diğerleri, 2016) davranışsal niyet üzerindeki etkisini ortaya koyan araştırmaları destekler niteliktedir. Dolayısıyla teknolojik bilgi ve beceri düzeyi düşük tüketiciler için kullanımı kolaylaştıracak site içi arama özelliğinin eklenmesi, basit ara yüze sahip site ve uygulamaların geliştirilmesi ile sanal marketin günlük hayatı kolaylaştıracak etkilerinin pazarlama iletişimi mesajlarıyla duyurulması faydalı olacaktır. Ayrıca alışkanlığın alışveriş yapma niyetini artırıcı etkisi göz önünde bulundurularak, potansiyel tüketicilerin bu kanalları denemelerini sağlayacak özel promosyon ve indirimler uygulanabilir. Diğer taraftan çaba beklentisi, hedonik motivasyon, fiyat-değer ve sosyal etkinin alışveriş yapma niyeti üzerinde anlamlı etkisinin olmadığ bulgusu elde edilmiştir.

Risk algılarının sanal market alışverişi yapma niyeti üzerindeki etkisi ile ilgili elde edilen bulgular psikolojik riskin negatif yönlü ve zaman riskinin pozitif yönlü etkisinin olduğunu göstermektedir. Psikolojik risk ile ilgili elde edilen bulgu, çevrimiçi alışveriş yapma niyetinde psikolojik riskin önemli bir etken olduğunu gösteren çalışmaları (Almousa, 2014; Chen, 2013; Ilmudeen, 2018; Masoud, 2013) desteklemektedir. Sanal market alışverişlerinde satın alınan, özellikle ambalajsız (sebze, meyve vb.) ürünlerin, başkası tarafından dokunularak alınması ürünlerden iğrenilmesine (Argo ve diğerleri, 2006) ve alışveriş yapma 
niyetinin azalmasına sebep oluyor olabilir. Bu durum göz önünde bulundurularak firmaların ürün seçimini titizlik ve özenle gerçekleştirdiklerini gösteren pazarlama iletişimi mesajlarına yer verilmesi psikolojik risk algısının azaltılmasında faydalı olabilir. Ayrıca ürün alternatiflerinin fazla sunulduğu bu kanallarda yapılan alışverişler fırsat maliyetlerden kaynaklı olarak mutsuzluk ya da tatminsizlik yaratıyor olabilir. Literatürde (Chernev, 2003; Kinjo ve Ebina, 2014; Shah ve Wolford, 2007) seçim paradoksu (the paradox of choice) olarak adlandırılan bu durumdan dolayı firmalar, ürün çeşitliliği konusunda optimal sınırlarını belirleyerek psikolojik riski azaltabilirler.

Risk algılarının sanal market alışverişini negatif yönlü etkilemesinin beklendiği çalışmada, zaman riskinin pozitif yönlü etkisi beklenmeyen bir durumdur. Literatürde çevrimiçi alışveriş yapma niyetinde risk algılarının etkisini inceleyen birçok çalışmada, zaman riskinin anlamlı etkisinin olmadığ1 ortaya konulmuştur (Chen, 2013; Mosoud, 2013; Sreya ve Raveendran, 2016). Fiziksel kanallarda farklı marketleri ziyaret ederek sadakatli oldukları markalara yönelik fiyat araştırması yapan tüketiciler, sanal market alışverişi ile bunu çok daha kolay bir şekilde gerçekleştirebilmektedirler. Dolayısıyla bu kanallarda geçirilen zaman bir risk olarak algilanmaktan ziyade fayda olarak algılanıyor olabilir.

Araştırmanın en büyük kısıtlarından biri tesadüfi olmayan araştırma yöntemlerinden kolayda örnekleme yönteminin kullanılmasıdır. Dolayısıyla araştırmadan elde edilen sonuçlar tüm tüketiciler için genellenemez. Gelecek araştırmalarda belirli alt gruplara (anneler, çalışan kadınlar, yaşlı bireyler vb.) odaklanılarak tüketicilerin sanal market alışverişi yapma niyetleri ile ilgili daha derin içgörüler elde edilebilir. Ayrıca hızlı tüketim ürünlerinin tek bir kategori altında ele alınmasından ziyade; ambalajl-ambalajsız ürünler, meyve-sebze gibi farklı ürün kategorilerine göre araştırmanın özelleştirilmesi daha faydalı bulgular elde edilmesini sağlayabilir.

\section{Kaynakça}

Alalwan, A. A., Dwivedi, Y. K., Rana, N. P., ve Algharabat, R. (2018). Examining factors influencing Jordanian customers' intentions and adoption of internet banking: Extending UTAUT2 with risk. Journal of Retailing and Consumer Services, 40, 125-138.

Almousa, M. (2014). The influence of risk perception in online purchasing behavior: Examination of an early-stage online market. International Review of Management and Business Research, 3(2), 779-787.

An, L., Tong, L. ve Han,Y. (2016). Study on the factors of online shopping intention for fresh agricultural products based on UTAUT2. 2nd Information Technology and Mechatronics Engineering Conference (ITOEC 2016), 303-306.

Argo, J. J., Dahl, D. W. ve Morales, A.C. (2006). Consumer contamination: How consumers react to products touched by others. Journal of Marketing, 70(2), 81-84.

Bambauer-Sachse, S. ve Mangold, S. (2011). Brand equity dilution through negative online wordofmouth communication. Journal of Retailing and Consumer Services, 18, 38-45.

Bauerová, R. ve Klepek, M. (2018). Technology acceptance as a determinant of online grocery shopping adoption. Acta Universitatis Agriculturae Et Silviculturae Mendelianae Brunensis, 66 (3), 737746.

Benbasat, I. ve Barki, H. (2007). Quo vadis TAM?. Journal of Association of Information Systems, 8(4), 211218.

Berg, J., ve Henriksson, M. (2020). In search of the "good life": Understanding online grocery shopping and everyday mobility as social practices. Journal of Transport Geography, 83. 
Candan, B. ve Kurtuluş, K. (2003). İnternet kullanıcılarının gıda, temizlik ve kişisel bakım ürünlerinde sanal alış-veriş yapma nedenlerini belirlemeye yönelik pilot bir araştırma. Atatürk Üniversitesi İktisadi ve İdari Bilimler Dergisi, 17 (1-2), 307-321.

Chen, ChauShen (2013). Perceived risk, usage frequency of mobile banking services. Journal of Service Theory and Practice, 23(5).

Chernev A (2003). When more is less and less is more: the role of ideal point availability and assortment in consumer choice. Journal of Consumer Research, 30(2), 170-183.

Chu, J., Arca-Urze, M. ve Cebollada-Calvo, J. (2010). An empirical analysis of shopping behaviour across online and offline channels for grocery products: The moderating effects of house hold and product characteristics. Journal of Interactive Marketing, 24 (4), 251-268.

Citrin, A. V., Stem, D. E, Spangenberg, E. R. ve Clark M. J. (2003). Consumer need for tactile input: an internet retailing challenge. Journal of Business Research, 56 (11), 915-922.

Davis, F. D., Bagozzi, R. P. ve Warshaw, P. R. (1989). User acceptance of computer technology: a comparison of two theoretical models. Management Science, 35, 982-1003.

Doherty, N. F. ve Ellis-Chadwick, F. (2009). Exploring the drivers, scope and perceived success of ecommerce strategies in the uk retail sector. European Journal of Marketing, 43 (9), 1246-1262.

Dowling, G.R. ve Staelin, R. (1994). A model of perceived risk and intended risk-handling activity, Journal of Consumer Research, 21, 119-134

Driediger, F. ve Bhatiasevi, V. (2019). Online grocery shopping in thailand: consumer acceptance and usage behavior. Journal of Retailing and Consumer Services, 48, 224-237.

Droogenbroeck, V. E. ve Hove, V. L. (2017). Adoption of online grocery shopping: personal or household characteristics?. Journal of Internet Commerce, 16(3), 255-286.

Durmuş, B., Yurtkoru, S. ve Çinko, M. (2016). Sosyal bilimlerde SPSS'le veri analizi. Beta Yayınları, İstanbul (Altıncı Bask1).

Escobar-Rodríguez, T .ve Carvajal Trujillo, E. (2013). Online drivers of consumer purchase of web site airline tickets", Journal of Air Transport Management, 32, 58-64.

Espegren, Y., Carling, K. ve Olsmants, C. (2018). Smart online grocery delivery and peri-urban consumers' attitudes, Dalarna University.

European Commission (2015). Methodological manual for statistics on the information society. https://circabc.europa.eu/faces/jsp/extension/wai/navigation/container.jsp.

Ferreira, M. P. (2009). (R)evolution of e-grocery industry: strategic implications. Universidade Católica Portuguesa (Porto).

Gefen, D. ve Straub, D. W. (2004). Consumer trust in B2C e-commerce and the importance of social presence: experiments in e-products and e-services. The International Journal of Management Science, 32: $407-424$.

Gegez, E. (2015). Pazarlama Araştırmaları. Beta Yayınları, İstanbul (Beşinci Baskı).

Gore, D. (2017). Everything you wanted to know about india's largest online süper market bigbasket. com!", http://techstory.in/bigbasket.

Gupta, S., Dogra, N. ve George, B. (2018). What determines tourist adoption of smartphone apps?: An analysis based on the UTAUT-2 framework. Journal of Hospitality and Tourism Technology, 9 (1), 5064.

Gupta, S. ve Kim, H. (2010). Value-driven internet shopping: the mental accounting theory perspective. Psychology and Marketing, 27 (1), 13-35. 
Güsken, S. R., Janssen, D., Hees, F., (2019). Online grocery platforms - understanding consumer acceptance. Conference Proceedings of the ISPIM Connects Ottawa.

Ha, H. (2002). The effects of consumer risk perception on pre-purchase information in online auctions: brand, word-of-mouth, and customized information. Journal of Computer-Mediated Communication, 8 (1).

Hassan, A. M., Kunz, M. B., Pearson, A.W. ve Mohamed, F.A. (2006). Conceptualization and measurement of perceived risk in online shopping. The Marketing Management Journal, 16(1), 138147.

Horton, R. L. (1976). The structure of perceived risk: Some further progress. Journal of the Academy of Marketing Science, 4, 694-706.

Huang, Y., ve Oppewal, H. (2006). Why consumers hesitate to shop online: an experimental choice analysis of grocery shopping and the role of delivery fees. International Journal of Retail $\mathcal{E}$ Distribution Management. 34 (4-5), 334-353.

Hwang, J., Yoon, Y. ve Park, N. (2011). Structural effects of cognitive and affective responses to web advertisements, website and brand attitudes, and purchase intentions: the case of casual-dining restaurants. International Journal of Hospitality Management, 30(4), 897-907.

Ilmudeen, A. (2018). Consumers' perceived security risks in online shopping: a survey study in Sri Lanka. Jaffna:Faculty of Management Studies \& Commerce.

İşçioğlu, T. E. (2017). Sanal market alışverişi niyetinin sürekliliğini etkileyen unsurlar ve bir model önerisi, Pazarlama ve Pazarlama Araştırmaları Dergisi, 21, 99-124.

Jacoby, J. ve Kaplan, L.B. (1972). The components of perceived risk. Annual Conference of the Association for Consumer Research. 382-393

Kaur, M. (2018). Customer relationship management in online grocery stores. Journal of Business $\mathcal{E}$ Financial Affairs, 7(2).

Kian, T. P., Loong, C. W. ve Fong, S. W. L. (2019). Customer purchase intention on online grocery shopping. International Journal of Academic Research in Business and Social Sciences, 8(12), 1579-1595.

Kim, S. S., ve Malhotra, N. K. (2005). A longitudinal model of continued IS use: an integrative view of four mechanisms underlying postadoption phenomena. Management Science, 51, 741-755.

Kinjo, K. ve Ebina, T. (2014). Paradox of choice and consumer nonpurchase behavior. AI \& Society, 30(2), 291-297.

Kureshi, S. ve Thomas, S. (2019). Online grocery retailing - exploring local grocers beliefs, International Journal of Retail \& Distribution Management, 47 (2), 157-185.

Li, H., Sarathy, R. ve Xu,H. (2011). The role of affect and cognition on online consumers' decision to disclose personal information to unfamiliar online vendors. Decision Support System, 51(3), 434-445.

Lim, H., R. Widdows ve Hooker, N. H. (2009). Web content analysis of e-grocery retailers: a longitudinal study. International Journal of Retail \& Distribution Management, 37 (10), 839-851.

Limayem, M., Hirt, S. G., ve Cheung, C. M. K. (2007). How habit limits the predictive power of intention: the case of information systems continuance. MIS Quarterly, 31(4), 705-737.

Loketkrawee, P. ve Bhatiasevi, V. (2018). Elucidating the behavior of consumers toward online grocery shopping: the role of shopping orientation. Journal of Internet Commerce, 17(4), 418-445.

Martinez, O., Tagliaferro, B., Rodriguez, N., Athens, J., Abrams, C. ve Elbel, B. (2018). Ebt payment for online grocery orders: a mixed-methods study to understand its uptake among snap recipients and the barriers to and motivators for its use. Journal of Nutrition Education and Behavior, 50(4), 396-402. 
Masoud, E. Y. (2013). The effect of perceived risk on online shopping in Jordan. European Journal of Business and Management, 5(6), 76-87.

McCorkle, D.E. (1990). The role of perceived risk in mail order catalog shopping. Journal of Direct Marketing, 4, 26-35.

Mortimer,G., Fazal, Hasan, S., Andrews, L. ve Martin, J. (2016). Online grocery shopping: the impact of shopping frequency on perceived risk, The International Review of Retail, Distribution and Consumer Research, 26(2).

Negahban, A. ve Chung, C. H. (2014). Discovering determinants of users perception of mobile device functionality fit. Computers in Human Behavior, 35, 75-84.

Nielsen (2019), “Türkiye'de FMCG Trendleri ve E-Ticaret” https://digitalage.com.tr/wpcontent/uploads/2019/06/Nielsen-Sunumu_ET\%C4\%B0K.pdf.

Park, E. J., Kim, E.Y., Funches, V.M. ve Foxx, W. (2012). Apparel product attributes, web browsing, and e-impulse buying on shopping websites. Journal of Business Research, 65 (11), 1583-1589.

Paulo, M., Paulo, R., Tiago, O. ve Sérgio, M. (2018) Understanding mobile augmented reality adoption in a consumer context, Journal of Hospitality and Tourism Technology, 9 (2), 142-157.

Picot-Coupey, K., Huré, E., Cliquet, G., ve Petr, C. (2009). Grocery shopping and the internet. The International Review of Retail, Distribution and Consumer Research (4): 437-455.

Rogus, S., Guthrie, J. F., Niculescu, M., ve Mancino, L. (2019). Online grocery shopping knowledge, attitudes, and behaviors among snap participants. Journal of Nutrition Education and Behavior.

Roselius, T. (1971). Consumer rankings of risk reduction methods. Journal of Marketing, 35, 56-61.

Seitz, C., Pokrivcak, J., Toth, M. ve Plevny, M. (2017). Online grocery retailing in germany: an explorative analysis. Journal of Business Economics and Management, 18(6), 1243-1263.

Shah A.M. ve Wolford G. (2007). Buying behavior as a function of parametric variation of number of choices. Psychological Science, 18(5), 369-370.

Shaw, N. ve Sergueeva, K. (2019). The non-monetary benefits of mobile commerce: Extending UTAUT2 with perceived value. Journal of International Management, 45, 44-55.

Singh, M. ve Matsui, Y. (2017). How long tail and trust affect online shopping behavior: an extension to utaut2 framework. Pacific Asia Journal of the Association for Information Systems, 9(4), 1-24.

Singh, R., ve Rosengren, S. (2020). Why do online grocery shoppers switch? An empirical investigation of drivers of switching in online grocery. Journal of Retailing and Consumer Services, 53.

Sreeram, A., Kesharwani, A. ve Desai, S. (2017). Factors affecting satisfaction and loyalty in online grocery shopping: an integrated model, Journal of Indian Business Research, 9 (2), 107-132.

Sreya, R. ve Raveendran, P.T. (2016). Dimensions of perceived risk in onlıne shopping - a factor analysis approach, BVIMSR's Journal of Management Research, 8 (1), 13- 18.

Statista (2017), “Online or in-store shopping preference for selected product categories by consumers worldwide as of 2017", https://www.statista.com/statistics/692871/global-online-shoppingpreference-by-category.

Stofega, W. ve Llamas, R.T. (2009). Worldwide converged mobile device phone 2009-2013 forecast update, IDC Document No. 217209, IDC.

Stone, R. ve Gronhaug, K. (1993). Perceived risk: further considerations for the marketing discipline, European Journal of Marketing, 27 (3), 39-50. 
Tabachnick, B.G. ve Fidell, S. L. (2015). Çok değişkenli istatistiklerin kullanımı. Nobel Akademik Yayıncilik.

Tak, P. ve Panwar, S. (2017). Using utaut 2 model to predict mobile app based shopping: evidences from india, Journal of Indian Business Research, 9 (3), 248-264.

Tandon, U., Kiran, R., ve Sah, A. N. (2016). Understanding online shopping adoption in india: unified theory of acceptance and use of technology 2 (UTAUT2) with perceived risk application. Service Science, 8(4), 420-437.

Teller, C., Kotzab, H. ve Grant, D. (2006). The consumer direct services revolution in grocery retailing: an exploratory investigation. Managing Service Quality, 16(1), 78-96.

Tsiros, M., ve C. M. Heilman (2005). The effect of expiration dates and perceived risk on purchasing behavior in grocery store perishable categories. Journal of Marketing, 69 (2), 114-129.

TUIK (2019), Hanehalkı Bilişim Teknolojileri Kullanım Araştırması, http://www.tuik.gov.tr/PreTablo.do?alt_id=1028

Twentify (2018), “Türkiye'de E-ticaret: Çevrimiçi Alışverişte Tüketici Davranışları Araştırması ve Marka Karşılaştırması", Araştırma Raporu.

Venkatesh, V. L., Morris, M., Davis, G. ve Davis, F. (2003). User acceptance of information technology: towards aunified view. MIS Quarterly, 27 (3), 425-477.

Venkatesh, V. L., Thong, J. Y., ve Xu, X. (2012). Consumer acceptance and use of information technolgy: extending the unified theory of acceptance and use of technology. MIS Quarterly, 36 (1), 157-178.

Verhoef, P. C., Langerak, F. (2001). Possible determinants of consumers' adoption of electronic grocery shopping in the Netherlands. Journal of Retailing and Consumer Services, 275- 285.

Yılmaz, C. (2015). İnternet üzerinden alışveriş niyetini etkileyen faktörlerin genişletilmiş teknoloji kabul modeli kullanarak incelenmesi ve bir model önerisi. Yönetim ve Ekonomi: Celal Bayar Üniversitesi İktisadi ve İdari Bilimler Fakültesi Dergisi, 22(2), 355-384.

Weber, A.ve Badenhorst-Weiss, J. (2018). The 'new' bricks-and-mortar store: an evaluation of website quality of online grocery retailers in BRICS countries, African Journal of Science, Technology, Innovation and Development, 10 (1), 85-97. 